\title{
Removal of Cr (VI) from Tannery Effluent and Aqueous Solution by Sequential Treatment with Microfungi and Basidiomycete-Degraded Sawdust
}

\author{
Bernard 0. Ejechi*, Olubunmi 0. Akpomie \\ Department of Microbiology, Delta State University, Abraka, Nigeria \\ Email: "ejechiben@gmail.com
}

Received 10 March 2016; accepted 8 May 2016; published 11 May 2016

Copyright (C) 2016 by authors and Scientific Research Publishing Inc.

This work is licensed under the Creative Commons Attribution International License (CC BY). http://creativecommons.org/licenses/by/4.0/

(c) (i) Open Access

\begin{abstract}
Removal of Cr (VI) from aqueous solution and tannery effluent in sequence with $\mathrm{Cr}$ (VI) resistant microfungi (Aspergillus niger, Penicillium chrysogenum) and sawdust degraded by basidiomycete (Gloeophyllum sepiarium) was investigated in the laboratory. Initial or primary treatment with microfungi reduced $200 \mathrm{mg} / \mathrm{l} \mathrm{Cr}(\mathrm{VI})$ in aqueous solution by $64.6 \%-78.2 \%$ while a markedly lower $0.52 \mathrm{mg} / \mathrm{l} \mathrm{Cr}$ (VI) in tannery effluent was reduced by $72.4 \%-84.6 \%$. However, the residual $\mathrm{Cr}$ (VI) in both aqueous solution and tannery effluent was reduced to a non-detectable level after secondary treatment by passage through basidiomycete-degraded sawdust column. The recovery of $65.4 \%-87.7 \%$ of the $\mathrm{Cr}$ (VI) removed by treatment microfungi by elution indicated adsorption as the major mechanism for $\mathrm{Cr}$ (VI) removal. The microfungi reduced BOD in tannery effluent by $85.3 \pm 5.6-92.7 \pm 6.8$ and concomitantly removed $\mathrm{Cr}$ (VI), hence it is hypothesized that non-Cr (VI) constituents of tannery effluent may have interfered with biosorption of $\mathrm{Cr}$ (VI) by treatment microfungi. It is concluded that the two-stage sequential treatment process may be of potential cost-saving stratagem for removal of chromium from industrial wastes.
\end{abstract}

\section{Keywords}

Chromium, Tannery Effluent, Gloeophyllum, Aspergillus, Penicillium, Sawdust

\section{Introduction}

The tanning industry generates wastes which include compounds such as chromium, phenol, chloride sulphide

${ }^{*}$ Corresponding author.

How to cite this paper: Ejechi, B.O. and Akpomie, O.O. (2016) Removal of Cr (VI) from Tannery Effluent and Aqueous Solution by Sequential Treatment with Microfungi and Basidiomycete-Degraded Sawdust. Journal of Environmental Protection, 7, 771-777. http://dx.doi.org/10.4236/jep.2016.76069 
tannins and formaldehyde among others [1] [2]. Chromium especially the hexavalent form is very toxic [3], hence industrial wastes containing chromium are usually treated before discharge. Physical and chemical technology methods are the conventional means of removing chromium from wastes, but the cost is often unbearable for the low-income countries. Microorganisms have therefore been investigated for their ability to remove chromium and other metals from aqueous solutions or industrial wastes in several studies [3]-[7]. Succinctly, these reports show that microorganisms can mobilize or immobilize metals by biosorption, sequestration, production of chelating agents, chemoorganotrophic and autotrophic leaching, methylation and redox transformations. These mechanisms stem from prior exposure of microorganisms to metals which enable them to develop the resistance and tolerance useful for biological treatment [8]. It has also been shown that cells of plants, algae, fungi and bacteria, otherwise referred to as biomass, possess functional groups such as carboxyl, hydroxyl, sulphate, phosphate and amino that can bind metals [9].

Despite their tolerance of metals, microorganisms are not always able to remove the metals completely from industrial wastes. For example [10] reported that Aspergillus and Micrococcus isolated from soil samples of an electroplating industry tolerated $\mathrm{Cr}$ (VI) toxicity up to 10,000 and $8000 \mathrm{mg} / \mathrm{l}$, respectively, but did not achieve $100 \%$ removal from a $100 \mathrm{mg} / 1$ solution despite the high tolerance. Some studies [11]-[15] have also shown that removal of $\mathrm{Cr}$ (VI) from tannery effluent by microorganisms was rarely $100 \%$ effective even with nutritional amendment. This can be attributed to limited binding sites on the microbial biomass or interference by other pollutants. It will therefore be desirable to find a second phase low cost treatment that can remove the residual chromium after initial treatment by microorganisms.

Aromatic compounds produced by some wood rot fungi during wood decomposition, include carboxyl, methoxyl and hydroxyl groups [16]-[18] that can also act as metal-binding agents. It is therefore hypothesized that introducing basidiomycete degraded sawdust as a second step to the treatment process began by microorganisms can remove the remaining $\mathrm{Cr}$ (VI) in the tannery effluent or aqueous solutions. This hypothesis was therefore tested using $\mathrm{Cr}$ (VI) resistant Penicillium chrysogenum and Aspergillus niger (microfungi) isolated from tannery effluent-contaminated soil, and obeche wood (Triplochyton scleroxylon) sawdust degraded by the basidiomycete Gloeophyllum sepiarium.

\section{Materials and Methods}

\subsection{Source of Cr (VI) Resistant Microfungi}

The test $P$. chysogenum and $A$. niger were isolated from tannery effluent-contaminated soil in Kano, Northern Nigeria in preliminary studies. Both microfungi tolerated $\mathrm{Cr}$ (VI) concentrations of $500 \mathrm{mg} / \mathrm{l}$ in potato dextrose medium.

\subsection{Inoculum Development}

The test P.chrysogenum, A. niger and G. sepiarium were each propagated in $150 \mathrm{ml}$ flasks containing potato dextrose broth made up to $50 \mathrm{ml}$ level mark for uniformity. They were incubated statically at room temperature $\left(30^{\circ} \mathrm{C} \pm 2^{\circ} \mathrm{C}\right)$ till growth covered the entire surface of the medium in order to ensure that the same standard of mycelial inoculum was generated. The mycelia were subsequently harvested by filtration with Whatman filter paper No 1 and washed several times with sterile distilled water to remove any adhering growth medium. This was the standard inoculum used for the treatment tests.

\subsection{Primary Treatment of Tannery Effluent and Aqueous Cr (VI) Solution}

The effluent used for the tests was collected from a tannery located in Kano, Northern Nigeria. The level of Cr (VI) in the effluent was determined by the atomic absorption spectrophotometer method of [19] before treatment after filtration with Whatman No 1 filter paper to remove suspended solids. Thereafter $250 \mathrm{ml}$ flasks containing $100 \mathrm{ml}$ filtered and autoclave-sterilised effluent were inoculated with test fungal mycelia (developed as described earlier) and agitated on an incubator-shaker $(150 \mathrm{rpm})$ at room temperature for up to $48 \mathrm{~h}$. A total of 24 flasks were prepared and 3 were withdrawn at 6-hourly intervals, filtered to remove hyphal strands, and analysed for $\mathrm{Cr}$ (VI) and BOD by the procedure of [19]. The duration it took to achieve maximum removal of $\mathrm{Cr}$ (VI) was recorded and used for subsequent experiments. The procedure was repeated with 10 replicate $250 \mathrm{ml}$ flasks incubated for the pre-determined duration and subsequently filtered to remove microfungal mycelia. The- 
reafter the residual $\mathrm{Cr}(\mathrm{VI})$ was determined before the filtrates were set aside for secondary treatment. The concentration of $\mathrm{Cr}(\mathrm{VI})$ removed was the difference between the initial concentration in the tannery effluent and the residual $\mathrm{Cr}(\mathrm{VI})$ after treatment with the microfungi. This was expressed as percentage of the initial concentration. The above procedure was repeated using microfungi killed by autoclaving at $120^{\circ} \mathrm{C}$ for 15 minutes or $G$. sepiarium as substitutes for the live treatment microfungi. The procedure outlined above was again repeated using $200 \mathrm{mg} / \mathrm{l} \mathrm{Cr}$ (VI) prepared from $\mathrm{K}_{2} \mathrm{Cr}_{2} \mathrm{O}_{7}$.

The ability of microfungal mycelia recovered from treated tannery effluent to remove $\mathrm{Cr}$ (VI) from aqueous solution was tested. The mycelia were recovered by filtration and washed with $0.1 \mathrm{M}$ Tris- $\mathrm{HCl}$ buffer $\mathrm{pH} 7.8$ [20] and sterile distilled water twice to remove adsorbed chromium and other tannery constituents. Thereafter, 10 replicate flasks containing $200 \mathrm{mg} / \mathrm{l}$ aqueous solution of $\mathrm{Cr}(\mathrm{VI})$ were inoculated with the mycelia and incubated as before. The $\mathrm{Cr}(\mathrm{VI})$ concentration was analyzed after the incubation period and the concentration of $\mathrm{Cr}$ (VI) removed was expressed as a percentage of the initial concentration $(200 \mathrm{mg} / \mathrm{l})$.

\subsection{Secondary Treatment}

Obeche wood (Triplochiton scleroxylon) sawdust was collected from sawmills, dried to constant weight at $105^{\circ} \mathrm{C}$, and dispensed at $50 \mathrm{~g} / 250 \mathrm{ml}$ flask. The sawdust was moistened with $20 \mathrm{ml}$ distilled water and autoclaved at $120^{\circ} \mathrm{C}$ for 30 mins. On cooling, the flasks were inoculated with $10 \mathrm{ml}$ Potato Dextrose Broth suspension of macerated mycelia of Gloeophyllum sepiarium (brown-rot basidiomycete) that was developed as described previously and manually turned over to effect sawdust/hyphal even mixture. The flasks were divided into 3 sets of 5 replicates bringing it to a total of 15 and set aside on the laboratory bench at room temperature for 3 months. They were moistened with $10 \mathrm{ml}$ sterile distilled water/flask at weekly intervals to prevent desiccation. A set of 5 flasks were retrieved at intervals of 4 weeks, manually macerated to break the hyphae/sawdust entanglement and dried to $30 \%$ moisture content at $45^{\circ} \mathrm{C}$ in a dessicator. This temperature was chosen to minimise any damage to potential $\mathrm{Cr}$ (VI) binding biomolecule that may be present. Thereafter they were aseptically packed into 5 replicate glass columns with an inner diameter of $4 \mathrm{~cm}$ and a height of $15 \mathrm{~cm}$. The filtrates of effluents or aqueous solution from primary treatment were passed through the degraded sawdust column at a drop/second from a burette. The effluents collected from the outlet at the bottom of the column were analyzed for $\mathrm{Cr}$ (VI) concentration. For the purpose of control, the above experiment was repeated with un-degraded sawdust as substitute for the basidiomycete-degraded sawdust. The concentration of $\mathrm{Cr}$ (VI) removed was expressed as percentage of the residual concentration in the filtrates from the primary treatment.

\subsection{Biosorption Capacity Tests}

Another set of microfungal mycelia were retrieved after primary treatment, dried overnight at $70^{\circ} \mathrm{C}$, and transferred to flasks containing $0.1 \mathrm{M}$ Tris-HCl buffer solution ( $\mathrm{pH}$ 7.8). They were shaken overnight at $200 \mathrm{rpm}$ to allow desorption of $\mathrm{Cr}(\mathrm{VI})$ occur. The filtrates were subsequently analyzed for desorbed $\mathrm{Cr}(\mathrm{VI})$ and expressed as percentages of the concentrations adsorbed during primary treatment. The degraded sawdust in the glass column were also retrieved after secondary treatment and similarly desorbed.

\section{Results and Discussion}

The Cr (VI) removed from tannery effluent and aqueous solution by the microfungi peaked at the $36^{\text {th }}$ hour of incubation (Figure 1). On the other hand $\mathrm{Cr}$ (VI) concentration removed by the basidiomycete was low and did not peak by the end of the incubation period (Figure 1). A $36 \mathrm{~h}$ incubation period was therefore adopted for subsequent tests.

The results of the primary treatment tests showed that the live microfungi removed over $70 \%$ of the chromium in the tannery effluent and aqueous solution and concomitantly reduced BOD by over $80 \%$ in the same effluent (Table 1). This was not unexpected because several reports have shown that microorganisms are capable of removing heavy metals including $\mathrm{Cr}$ (VI) from industrial wastes or aqueous solutions [3] [10] [12] [13] [21]. The basidiomycete removed less than $10 \%$ of the $\mathrm{Cr}$ (VI) and could only reduce BOD by less than $20 \%$ (Table 1 ). This suggests that the capacity of G. sepiarium, a brown-rot fungus, to adsorb or remove Cr (VI) is limited although research reports indicate that some basidiomycetes like the white-rot Pleurotus species can remove substantial concentrations of $\mathrm{Cr}(\mathrm{VI})$ from waste water [22] [23]. The dead mycelia were unable to remove $\mathrm{Cr}(\mathrm{VI})$ or reduce BOD in tannery effluent to the extent that the live mycelia did (Table 1). However, the dead mycelia 


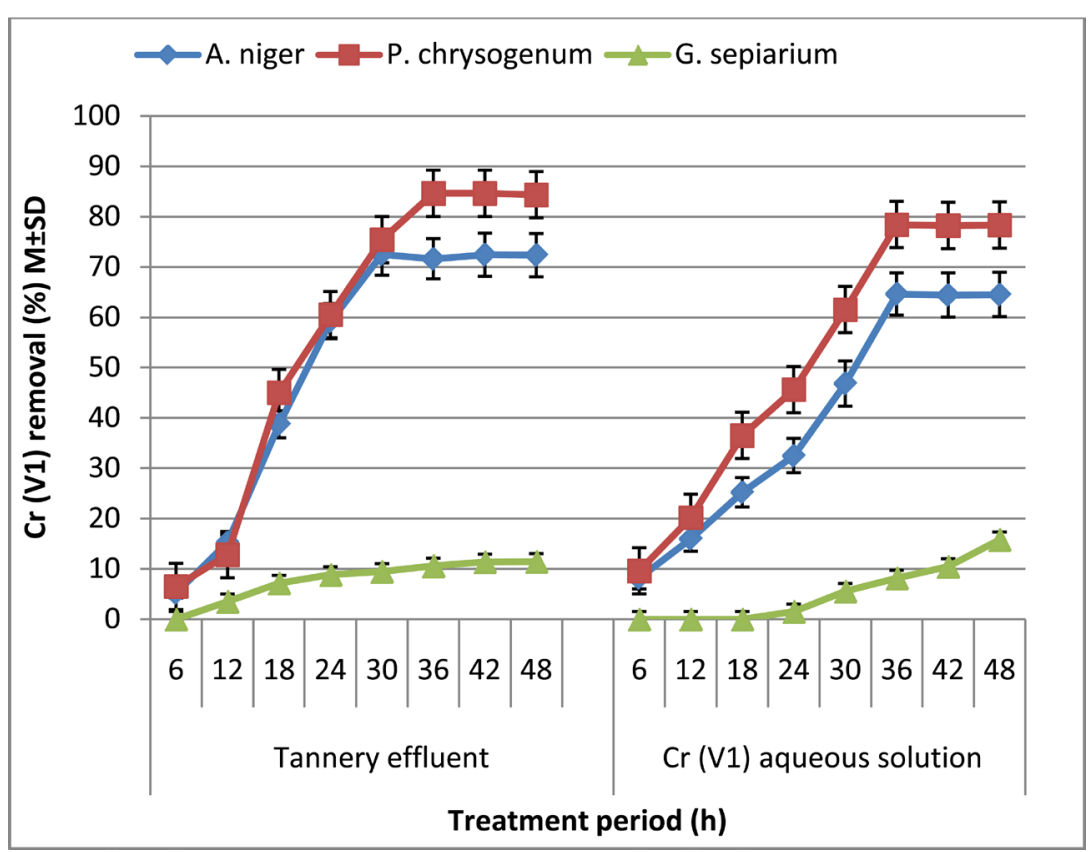

Figure 1. Removal of $\mathrm{Cr}$ (V1) from tannery effluent and aqueous solution. $\mathrm{Cr}$ (V1) concentration before treatment: tannery effluent $0.52 \pm 0.08 \mathrm{mg} / \mathrm{l}$; aqueous solution, $200 \mathrm{mg} / \mathrm{l}$.

Table 1. Removal of Cr (VI) in tannery effluent and aqueous solution by microfungi during primary treatment after $36 \mathrm{~h}$.

\begin{tabular}{|c|c|c|c|}
\hline \multicolumn{2}{|c|}{ Treatment organisms } & \multicolumn{2}{|c|}{ After treatment } \\
\hline Status & Organism & $\mathrm{Cr}(\mathrm{VI})$ removal (\%) $\mathrm{M} \pm \mathrm{SD}$ & ${ }^{*}$ BOD reduction (\%) $\mathrm{M} \pm \mathrm{SD}$ \\
\hline Live in tannery effluent & $\begin{array}{c}\text { As. niger } \\
\text { P. chrysogenum } \\
\text { G. sepiarium }\end{array}$ & $\begin{array}{c}72.5 \pm 4.2 \\
84.6 \pm 4.7 \\
9.6 \pm 1.2\end{array}$ & $\begin{array}{l}85.3 \pm 5.6 \\
92.7 \pm 6.8 \\
18.5 \pm 3.3\end{array}$ \\
\hline Dead in tannery effluent & $\begin{array}{l}\text { As. niger } \\
\text { P. chrysogenum } \\
\text { G. sepiarium }\end{array}$ & $\begin{array}{c}25.3 \pm 2.0 \\
32.1 \pm 2.1 \\
5.4 \pm 1.0\end{array}$ & $\begin{array}{l}0.0 \pm 0.0 \\
0.0 \pm 0.0 \\
0.0 \pm 0.0\end{array}$ \\
\hline Live in aqueous solution & $\begin{array}{l}\text { As. niger } \\
\text { P. chrysogenum } \\
\text { G. sepiarium }\end{array}$ & $\begin{array}{c}64.6 \pm 4.5 \\
78.2 \pm 4.8 \\
9.7 \pm 1.5\end{array}$ & $\begin{array}{l}\text { NA } \\
\text { NA } \\
\text { NA }\end{array}$ \\
\hline Dead in aqueous solution & $\begin{array}{c}\text { As. niger } \\
\text { P. chrysogenum } \\
\text { G. sepiarium }\end{array}$ & $\begin{array}{c}68.6 \pm 3.4 \\
71.7 \pm 4.3 \\
6.3 \pm 1.2\end{array}$ & $\begin{array}{l}\text { NA } \\
\text { NA } \\
\text { NA }\end{array}$ \\
\hline
\end{tabular}

Concentration of $\mathrm{Cr}(\mathrm{V} 1)$ before primary treatment: tannery effluent, $0.52 \pm 0.08 \mathrm{mg} / 1$; aqueous solution $200 \mathrm{mg} / \mathrm{l}$. ${ }^{*} \mathrm{BOD}$ concentration in tannery effluent before treatment $=1240.0 \mathrm{mg} / \mathrm{l}$. NA. Not applicable.

removed Cr (VI) from aqueous solution to an extent that was not markedly different from the level it was reduced to by the live mycelia (Table 1). While removal of metals by biomass is physical and depends on the chelating agents on biomass surface, removal of BOD is dependent on metabolic activity which dead cells cannot perform.

The BOD test results confirm the presence of compounds in the tannery effluent that can interfere with metal binding sites on the fungal mycelia. This inference is supported by the observation that despite the low concentration of $\mathrm{Cr}$ (VI) in tannery effluent, the microfungi were unable to achieve $100 \%$ removal rate. This contrasts sharply with the result showing the same fungal mycelia dead or alive, removing markedly higher concentrations of Cr (VI) in aqueous solution. Further evidence comes from the observation that the mycelia of $A$. niger and $P$. chysogenum recovered from primary treatment of tannery effluent was able to remove $115.4 \pm 5.3 \mathrm{mg} / \mathrm{l}$ $(57.7 \%)$ and $122.2 \pm 5.8 \mathrm{mg} / 1$ (61.1\%) $\mathrm{Cr}$ (VI), respectively from aqueous solution. This suggests that interfering tannery constituents may have been dislodged from the mycelia by the washings with Tris-HCL buffer and 
distilled deionised water. The limited $\mathrm{Cr}(\mathrm{VI})$ removal ability of dead mycelia in tannery effluent can be attributed to lack of metabolic activity that can degrade some of the tannery constituents that may have interfered with $\mathrm{Cr}$ (VI) binding sites on the mycelia.

The secondary treatment with $G$. sepiarium-degraded obeche wood sawdust removed the residual $\mathrm{Cr}(\mathrm{VI})$ in the tannery effluent and aqueous solution after primary treatment (with microfungi) to the extent that $\mathrm{Cr}$ (VI) could not be detected (Table 2). The results in Table 2 also show that this was achieved in obeche sawdust degraded for 8 weeks and above. Although basidiomycete-degraded sawdust was able to remove $\mathrm{Cr}$ (VI) from untreated tannery effluent, the concentration was markedly lower than that removed from treated effluent (Table 2).

On the other hand, removal of Cr (VI) in tannery effluent or aqueous solution (with or without primary treatment) by un-degraded obeche sawdust was marginal (Table 3). Two hypotheses arise from these two findings. The first is that compounds produced during wood degradation can act as metal chelating or binding agents that immobilised $\mathrm{Cr}$ (VI) hence $\mathrm{Cr}$ (VI) was not substantially removed in un-degraded sawdust. The second is that some constituents of the untreated tannery effluent may be blocking the potential $\mathrm{Cr}(\mathrm{VI})$ binding biomolecules released during decomposition of sawdust. Evidence for the first hypothesis comes from previous research findings that wood degrading basidiomycetes produce compounds during wood decomposition that can bind metals [16]-[18] [24]. For the second hypothesis, research needs to be directed towards interaction between tannery effluent constituents and fungal mycelia. The focus of future research will be to address this limitation.

The results presented in Table 4 indicate biosorption as the predominant mechanism for the removal of $\mathrm{Cr}$ (VI) by both the microfungi and in degraded sawdust, because over $50 \%$ of the $\mathrm{Cr}$ (VI) taken up was recovered

Table 2. Removal of Cr (VI) in filtrates from primary treatment by obeche wood sawdust degraded by basidiomycete G. sepiarium.

\begin{tabular}{ccccc}
\hline \multirow{2}{*}{ Source of filtrate } & Primary treatment organism & \multicolumn{3}{c}{ Removal of residual Cr (VI) (\%) by degraded sawdust after: } \\
\cline { 3 - 5 } & & 4 & 8 & 12 weeks \\
\hline \multirow{2}{*}{ Tannery effluent } & ${ }^{\mathrm{a}}$ A. niger & $96.5 \pm 5.3$ & $\mathrm{ND}$ & ND \\
& ${ }^{\mathrm{b}}$ P. chrysogenum & $97.4 \pm 5.5$ & $\mathrm{ND}$ & $\mathrm{ND}$ \\
Aqueous solution & ${ }^{\mathrm{c}}$ A. niger & $89.2 \pm 4.7$ & $\mathrm{ND}$ & $\mathrm{ND}$ \\
& ${ }^{\mathrm{d}}$ P. chrysogenum & $92.5 \pm 5.0$ & $\mathrm{ND}$ & $\mathrm{ND}$ \\
Untreated tannery effluent & Control & $59.3 \pm 3.6$ & $72.8 \pm 4.5$ & $75.2 \pm 4.5$ \\
\hline
\end{tabular}

$\mathrm{ND}$, Not detected. $\mathrm{Cr}(\mathrm{VI})$ in filtrate from primary treatment: ${ }^{\mathrm{a}} 0.14 \pm 0.03 \mathrm{mg} / \mathrm{l} ;{ }^{\mathrm{b}} 0.08 \pm 0.01 \mathrm{mg} / \mathrm{l} ;{ }^{\mathrm{c}} 70.8 \pm 3.6, \mathrm{mg} / 1 ;{ }^{\mathrm{d}} 44.5 \pm 3.0 \mathrm{mg} / \mathrm{l}$. Cr (VI) in: untreated tannery effluent, $0.52 \pm 0.08 \mathrm{mg} / 1$; aqueous solution, $200 \mathrm{mg} / \mathrm{l}$.

Table 3. Removal of residual Cr (V1) in filtrates from primary treatment by un-degraded obeche wood sawdust.

\begin{tabular}{ccc}
\hline Source of Cr (VI) & Primary treatment fungus & Removal of Cr (VI) in un-degraded sawdust (\%) $\mathbf{M} \pm \mathbf{S D}$ \\
\hline & ${ }^{\mathrm{a}}$ A. niger & $2.5 \pm 0.10$ \\
Tannery effluent & ${ }^{\mathrm{b}} P$. chrysogenum & $2.8 \pm 0.10$ \\
& Not treated & $1.6 \pm 0.10$ \\
& ${ }^{\mathrm{c}}$ A. niger & $5.4 \pm 0.15$ \\
Aqueous solution & ${ }^{\mathrm{d}} P$. chrysogenum & $5.8 \pm 0.15$ \\
& Not treated & $2.3 \pm 0.10$ \\
\hline
\end{tabular}

$\mathrm{Cr}(\mathrm{V} 1)$ in filtrate from primary treatment: ${ }^{\mathrm{a}} 0.14 \pm 0.03 \mathrm{mg} / \mathrm{l} ;{ }^{\mathrm{b}} 0.08 \pm 0.01 \mathrm{mg} / 1 ;{ }^{\mathrm{c}} 70.8 \pm 3.6, \mathrm{mg} / \mathrm{l} ;{ }^{\mathrm{d}} 44.5 \pm 3.0 \mathrm{mg} / \mathrm{l}$.

Table 4. Cr (VI) desorbed from fungal mycelia and G. sepiarium-degraded sawdust after treatment of tannery effluent and aqueous $\mathrm{Cr}$ (VI) solution.

\begin{tabular}{ccc}
\hline Source of $\mathbf{C r}(\mathbf{V I})$ & *Fungal mycelia & Desorbed Cr (VI) (\%) M \pm SD \\
\hline & Aspergillus niger & $86.5 \pm 4.0$ \\
Tannery effluent & Penicillium chrysogenum & $87.7 \pm 4.2$ \\
& Aspergillus niger & $65.4 \pm 3.6$ \\
Aqueous solution & Penicillium chrysogenum & $69.6 \pm 3.7$ \\
& NA & $52.5 \pm 3.3$ \\
\hline
\end{tabular}

NA, Not applicable; ${ }^{*}$ after primary treatment. 
by desorption. However the percentage of $\mathrm{Cr}$ (VI) recovered from degraded sawdust was markedly lower than that recovered from fungal mycelia (Table 4). This notwithstanding, it is an indication that the degraded wood can be re-used to reduce the cost of the treatment process.

\section{Conclusion}

The main objective was to complement chromium biosorption capacity of microfungi with biosorption capability of brown-rot wood decomposition products in a sequential arrangement. This was achieved because Cr (VI) was reduced to non-detectable level at the end of the two-phase treatment sequence. The live mycelium possesses a better potential for initial treatment of tannery effluent than the dead mycelia. The reason was that in addition to removing $\mathrm{Cr}$ (VI) better than the dead mycelia, it also metabolized other tannery constituents as indicated by BOD reduction which was not possible with dead mycelia. This strategy may prove useful in a cost-effective treatment stratagem for chromium removal in industrial wastes if further tests with other wastes prove successful. Low-income countries that cannot afford the cost of the conventional treatment technology may find it attractive especially as sawdust is an abundant, but often wasted resource in many developing countries like Nigeria.

\section{References}

[1] Mingshu, L.Y., Qiang, H. and Dongyin, J. (2006) Biodeterioration of Gallotannins and Ellagitannum. Journal of Basic Microbiology, 46, 68-84. http://dx.doi.org/10.1002/jobm.200510600

[2] Hasegaven, M.C., Barbosa, A.M. and Takashina, K. (2010) Biotreatment of Industrial Tannery Wastewater Using Bioryoshphariarhodiria. Journal of Serbia Chemical Society, 76, 1-8.

[3] Colin, L.V., Villegas, L.B. and Abate, C.M. (2012) Indigenous Microorganisms as Potential Bioremediators for Environments Contaminated with Heavy Metals. International Biodeterioration \& Biodegradation, 68, 28-37. http://dx.doi.org/10.1016/j.ibiod.2011.12.001

[4] Lovley, D.R. (2000) Fe (III) and Mn (IV) Reduction. In: Lovley, D.R., Ed., Environmental Microbe-Metal Interactions, American Society for Microbiology, Washington DC, 3-30. http://dx.doi.org/10.1128/9781555818098.ch1

[5] McLean, J. and Beveridge, T.J. (2001) Chromate Reduction by a Pseudomonad Isolated from a Site Contaminated with Chromate Copper Arsenate. Applied and Environmental Microbiology, 67, 1076-1084. http://dx.doi.org/10.1128/AEM.67.3.1076-1084.2001

[6] McLean, J.S., Lee, J.U. and Beveridge, T.J. (2002) Interaction of Bacteria and Environmental Metals, Fine-Grained Mineral Development and Bioremediation Strategies. In: Huang, P.M., Bollag, J.M. and Senesi, N., Eds., Interaction between Microorganisms and Soil Particles, Wiley, New York, 227-261.

[7] Ilias, M., Rafiqullah, I.M., Mannan, K.S.B. and Hoq, M.M. (2011) Isolation and Characterization of Chromium (VI)-Reducing Bacteria from Tannery Effluents. Indian Journal of Microbiology, 51, 76-81. http://dx.doi.org/10.1007/s12088-011-0095-4

[8] Viti, C. and Giovannetti, L. (2003) The Impact of Chromium Contamination on Soil Heterotrophic and Photosynthetic Microorganisms. Annals of Microbiology, 51, 201-213.

[9] Chandra, S.K., Kamala, C.T., Chary, N.S., Sastry, A.R., Nageswara, R.T. and Vairamani, M. (2004) Removal of Lead from Aqueous Solutions Using an Immobilized Biomaterial Derived from a Plant Biomass. Journal of Hazardous Material, 108, 111-117. http://dx.doi.org/10.1016/j.jhazmat.2004.01.013

[10] Congeevaram, S., Dhanarani, S., Park, J., Dexilin, M. and Thamaraiselvi, K. (2007) Biosorption of Chromium and Nickel by Heavy Metal Resistant Fungal and Bacterial Isolates. Journal of Hazardous Materials, 146, 270-277. http://dx.doi.org/10.1016/j.jhazmat.2006.12.017

[11] Louhab, K., Sahmoune, N., Addad, J. and Barr, S. (2008) Quality Improvement of Recycled Chromium in the Tanning Operation by Fermentation Waste. The 12th International Water Technology Conference, IWTC12 2008, Alexandria, 27-30 March 2008, 1-13. http://iwtc.info/archive

[12] Benazir, J.F., Suganthi, R., Rajvel, D., Pooja, M.P. and Mathithumilan, B. (2010) Bioremediation of Chromium in Tannery Effluent by Microbial Consortia. African Journal of Biotechnology, 9, 3140-3143.

[13] Mythili, K. and Karthikeyan, B. (2011) Bioremediation of Chromium [Cr (VI)] in Tannery Effluent Using Bacillus spp. and Staphylococcus spp. International Journal of Pharmaceutical \& Biological Archives, 2, 1460-1463.

[14] Sharma, S. and Adholeya, A. (2012) Hexavalent Chromium Reduction in Tannery Effluent by Bacterial Species Isolated from Tannery Effluent Contaminated Soil. Journal of Environmental Science and Technology, 5, 142-154. http://dx.doi.org/10.3923/jest.2012.142.154 
[15] Priya, K.S., Roja, K., Sakunthala, P.A., Sivasubramanian, A. and Muthuraman, M. (2013) Detoxification and Bioremediation of Chromium (VI) from the Tannery Effluents. International Journal of ChemTech Research, 5, 2177-2185.

[16] Goodell, B., Jellison, J., Daniel, G., Paszcynski, A., Fekete, F., Krishnamurthy, S., Jun, L. and Xu, G. (1997) Low Molecular Weight Chelator and Phenolic Compounds Isolated from Wood Decay Fungi and Their Role in Fungal Biodegradation of Wood. Journal of Biotechnology, 53, 133-162. http://dx.doi.org/10.1016/S0168-1656(97)01681-7

[17] Kerem, Z., Jensen, K.A. and Hammel, K.E. (1999) Biodegradative Mechanism of the Brown-Rot Basidiomycete Gloeophyllum trabeum: Evidence for an Extracellular Hydroquinone-Driven Fenton Reaction. FEBS Letters, 446, 4954. http://dx.doi.org/10.1016/S0014-5793(99)00180-5

[18] Paszcynski, A., Crawford, R., Funk, D. and Goodell, B. (1999) De Novo Synthesis of 4,5-Dimethoxycatechol and 2,5-Dimethoxyhydroquinone by Brown-Rot Fungus Gloeophyllum trabeum. Applied and Environmental Microbiology, 65, 674-679.

[19] American Public Health Association (APHA) (2005) Standard Methods for Analyses of Waste and Wastewater. American Public Health Association, Washington DC.

[20] Lokeshwari, N. and Joshi, K. (2009) Biosorption of Heavy Metal (Chromium) Using Biomass. Global Journal of Environmental Research, 3, 29-35.

[21] Gadd, G.M. (2004) Microbial Influence on Metal Mobility and Application for Bioremediation. Geoderma, 122, 109119. http://dx.doi.org/10.1016/j.geoderma.2004.01.002

[22] Javaid, A., Bajwa, R., Shafique, U. and Anwar, J. (2011) Removal of Heavy Metals by Adsorption on Pleurotus ostreatus. Biomass and Bioenergy, 35, 1675-1682. http://dx.doi.org/10.1016/j.biombioe.2010.12.035

[23] Suseem, S.R. and Mary, S.A. (2014) Biosorption of Heavy Metals Using Mushroom Pleurotus eous. Journal of Chemical and Pharmaceutical Research, 6, 2163-2168.

[24] Ejechi, B.O. (2003) Immobilization of Cu(II) and Cr(VI) in Basidiomycete-Colonized Sawdust. World Journal of Microbiology \& Biotechnology, 19, 135-137. http://dx.doi.org/10.1023/A:1023275522874 